\title{
KVALITETAN KNJIŽNIČNI SUSTAV - \\ PRETPOSTAVKA USPJEŠNOG RADA MATIČNE SLUŽBE KNJIŽNICA GRADA ZAGREBA
}

\author{
HIGH-QUALITY LIBRARY SYSTEM - A PRECONDITION \\ FOR THE SUCCESS OF THE CENTRAL LIBRARY \\ RESEARCH AND DEVELOPMENT DEPARTMENT \\ IN ZAGREB CITY LIBRARIES
}

\begin{abstract}
Maja Bodiš
Knjižnice grada Zagreba

maja.bodis@kgz.hr

Ivančica Đukec Kero

Knjižnice grada Zagreba

ivancica.dukec@kgz.hr

Kluk Giunio

Knjižnice grada Zagreba

kluk.giunio@kgz.hr
\end{abstract}

\author{
UDK / UDC 027.021:004 \\ Stručni rad / Professional paper \\ Prihvaćeno / Accepted: 24. 5. 2017.
}

\section{Sažetak}

Višegodišnji razvoj mrežnog integriranog knjižničnog sustava u Knjižnicama grada Zagreba osigurao je cjelovito računalno poslovanje u skladu s načelima struke. U radu su predstavljeni moduli Revizija i otpisi te Statistika, koji omogućuju pravovremenu provedbu zakonom propisanih poslova, poput revizije i otpisa knjižnične građe, kao i strukturiranje statističkih podataka na način da oni budu organizirani, dostupni i

Vjesnik bibliotekara Hrvatske 60, 1(2017), 155-172

ISSN 0507-1925

(C) VBH 2017. 
iskoristivi za praćenje pojedinih statističkih pokazatelja i njihove usporedbe kroz dulje vremensko razdoblje te planiranje za naredne godine. Korištenjem navedenih modula Matična služba KGZ-a uspješnije može provoditi stručni nadzor, unapređivati i sustavno razvijati knjižničnu djelatnost, što je prepoznato i među osnivačima te korisnicima. Osnivači zahvaljujući našoj mogućnosti povezivanja statističkih podataka mogu uvijek dobiti uvid u brojne stručne, statističke, ali i financijske pokazatelje, a korisnici i mediji uvijek svježe i pouzdane podatke o poslovanju knjižnice. Dostupnost i ovlašten pristup podacima olakšava rad djelatnika Matične službe u smislu brže i jednostavnije provjere strukturiranih pokazatelja, a mogućnost online pristupa pojedinoj lokaciji od strane djelatnika Matične službe omogućava pružanje podrške na daljinu djelatnicima koji rade u sustavu i racionalizaciju vremena.

Ključne riječi: integrirani knjižnični sustav ZaKi, Knjižnice grada Zagreba, Matična služba, revizija, otpisi, statistika, razvoj, nadzor, podrška na daljinu

\section{Summary}

After years of work on implementation and development, the integrated online library system ZaKi used in Zagreb City Libraries provides the complete computerized library management in accordance with the principles of the library profession. This paper presents two library modules: Weeding and Deselection and Statistics. They enable carrying out the regular library activities determined by legal regulations like weeding and deselection of library materials and structuring of statistical data in an organized form, easily accessible and suitable for the long term monitoring and comparison of certain statistical indicators as well as for help in making plans for the next year. By using these modules, the Central Library Research and Development Department (R\&D) can conduct supervision more successfully, and also promote and systematically develop various library activities. The benefits of using the modules have been recognized both by the library founders and by our users. The possibility of providing the statistical data analysis enables the library founders to have constant insight into different technical, statistical, and financial indicators. In addition, our users and the media have access to the newest and reliable library management data. Availability and authorized access to the data facilitates the work of the Central R\&D Department employees in terms of faster and easier verification of structured indicators, while the online access to each branch location by R\&D Department employees provides the remote support to employees within the system and rationalization of time.

Keywords: Integrated Library System ZaKi, Zagreb City Libraries, Central R\&D Department, weeding, deselection, statistics, development, supervision, remote support 


\section{Uvod}

Knjižnice grada Zagreba obavljaju temeljne i razvojne poslove matične djelatnosti za narodne i školske knjižnice u Gradu Zagrebu i Zagrebačkoj županiji. ${ }^{1}$ Kao zasebna ustrojbena jedinica koja obavlja poslove matičnosti i koordinira poslove ostalih ustrojbenih jedinica mreže te prati njihovu djelatnost, ustanovljena je Matična služba Knjižnica grada Zagreba. Njezina djelatnost obuhvaća niz poslova, među ostalim:

- praćenje, nadzor, savjetovanje i pomoć u stručnom radu i poslovanju knjižnica za koje su matični

- prikupljanje statističkih podataka o radu narodnih i školskih knjižnica² za koje su nadležni, kao i izradu i analizu skupnih izvještaja i programa rada tih knjižnica

- prikupljanje, analizu i međunarodnu razmjenu statističkih podataka (Metropolitan Libraries Section - Annual Statistics ${ }^{3}$, EBLIDA-ini ${ }^{4}$ upitnici i sl.). U svrhu olakšavanja procesa rada, Matična služba od početaka je uključena u tim stručnih djelatnika odgovoran za razvoj knjižničnog softvera $\mathrm{ZaKi}^{5}$, koji je osmišljen upravo s namjerom da u cijelosti prati kompleksno poslovanje prije svega narodnih, ali i drugih vrsta knjižnica. Razvijan je s namjerom da može pratiti zahtjeve struke, ali i potrebe jedne kompleksne mreže narodnih knjižnica kao što su Knjižnice grada Zagreba.

Među elaboratima Knjižnica grada Zagreba, pripremljenim prema europskim iskustvima, izdvajamo Idejni projekt informacijskog sistema narodnih knjižnica grada Zagreba (1987.) $)^{6}$ iz čega je vidljivo da ideja o informatizaciji zagrebač-

1 Status matične knjižnice dodjeljuje se na osnovi odluke ministra kulture, a u skladu sa Zakon o knjižnicama (NN 105/97, izmjene 5/98, 104/00, 69/09) i Pravilnikom o matičnoj djelatnosti knjižnica u Republici Hrvatskoj (NN 43/2001).

2 Nadležnost Matične službe Knjižnica grada Zagreba: 12 narodnih knjižnica, 47 osnovnoškolskih i 23 srednjoškolskih knjižnica u Zagrebačkoj županiji te 42 narodne knjižnice u mreži Knjižnica grada Zagreba i 112 osnovnoškolskih, 103 srednjoškolske knjižnice i 15 učeničkih domova u Gradu Zagrebu

3 Više na http://www.ifla.org/publications/annual-statistics.

4 EBLIDA (European Bureau of Library, Information and Documentation Associations - Europski biro knjižničnih, informacijskih i dokumentacijskih udruženja) je osnovana 1992. godine i orijentirana je na lobiranje za knjižnice i druge kulturne institucije, kao i uređenje knjižnične politike i legislative na europskoj razini. Knjižnice grada Zagreba članice su EBLIDA-e od 2010. godine te sudjeluju u godišnjim sastancima $i$ istraživanjima.

5 Na razvoju mrežnog integriranog knjižničnog sustava ZaKi tim stručnih djelatnika Knjižnica grada Zagreba surađuje s informatičkom tvrtkom Viva Info d.o.o. od 1997. godine. ZaKi je jedan od četiri najkorištenija sustava u hrvatskim knjižnicama.

6 Više o tome u Gomerčić, Nada. Matična služba Knjižnica grada Zagreba 1973.-1998. : 25 godina rada Matične službe. Zagreb : Knjižnice grada Zagreba, Matična služba, 1998. Str. 5-9. 
kih knjižnica seže unazad gotovo trideset godina. Cilj joj je bio doprinijeti kvalitetnijem razvoju mreže knjižnica te poboljšanju usluga, uz racionalno trošenje sredstava. Integrirani knjižnični sustav ZaKi plod je višegodišnjeg razvoja i kvalitetne timske suradnje u Knjižnicama grada Zagreba i od 1997. godine, kad je prva inačica programa instalirana u Gradsku knjižnicu Zagreb, pa sve do danas osigurava kompletno računalno poslovanje široke mreže knjižnica po načelima struke. Budući da se program konstantno razvija, i Matična služba koja je odgovorna za stručni nadzor, praćenje, unapređivanje i sustavno razvijanje knjižnične djelatnosti u području svoje nadležnosti, također sudjeluje u razvoju te u svom radu koristi sve što taj složeni program nudi. Nekada su djelatnici Matične službe imali znatno veću potrebu za izlascima na teren kako bi dobili izravan uvid u poslovanje knjižnica za koje su nadležni, kako bi im pružili pomoć i podršku i na taj način provodili svojevrstan nadzor nad kvalitetom njihova rada. Danas, budući da je poslovanje narodnih knjižnica pokriveno zajedničkim knjižničnim programom, više nema potrebe za toliko učestalim obilascima knjižnica. U radu su predstavljeni moduli Revizija i otpisi te Statistika, koji omogućuju pravovremenu provedbu zakonom propisanih poslova, poput revizije i otpisa knjižnične građe, kao i strukturiranje statističkih podataka na način da oni budu organizirani, dostupni i iskoristivi za praćenje pojedinih statističkih pokazatelja i njihove usporedbe kroz dulje vremensko razdoblje te planiranje za naredne godine. Korištenjem navedenih modula Matična služba KGZ-a uspješnije može provoditi stručni nadzor, unapređivati i sustavno razvijati te planirati knjižničnu djelatnost na svom području, što je prepoznato i među osnivačima te korisnicima. Zahvaljujući mogućnosti povezivanja raznovrsnih statističkih podataka, Matična služba može na zahtjev osnivača uvijek omogućiti uvid u brojne stručne, statističke, ali i financijske pokazatelje, a korisnici i mediji mogu dobiti uvijek svježe i pouzdane podatke o poslovanju knjižnice. Dostupnost i ovlašten pristup podacima olakšava rad djelatnika Matične službe u smislu brže i jednostavnije provjere strukturiranih pokazatelja, a mogućnost online pristupa pojedinoj lokaciji od strane djelatnika Matične službe omogućava pružanje podrške na daljinu djelatnicima koji rade u sustavu i racionalizaciju vremena na obostrano zadovoljstvo.

\section{Korištenje mrežnog integriranog knjižničnog sustava ZaKi u Ma- tičnoj službi}

Danas ZaKi koristi preko 260 knjižnica u Hrvatskoj, no za Matičnu službu Knjižnica grada Zagreba vrlo je važno da su uključene sve narodne knjižnice u Gradu Zagrebu i Zagrebačkoj županiji koje su u području njezine matičnosti, što znatno olakšava i pojednostavnjuje stručni nadzor. Za rad u pojedinim modulima programa djelatnicima se dodjeljuju ovlasti za rad prema vrsti posla i odgovornosti (slika 1). 


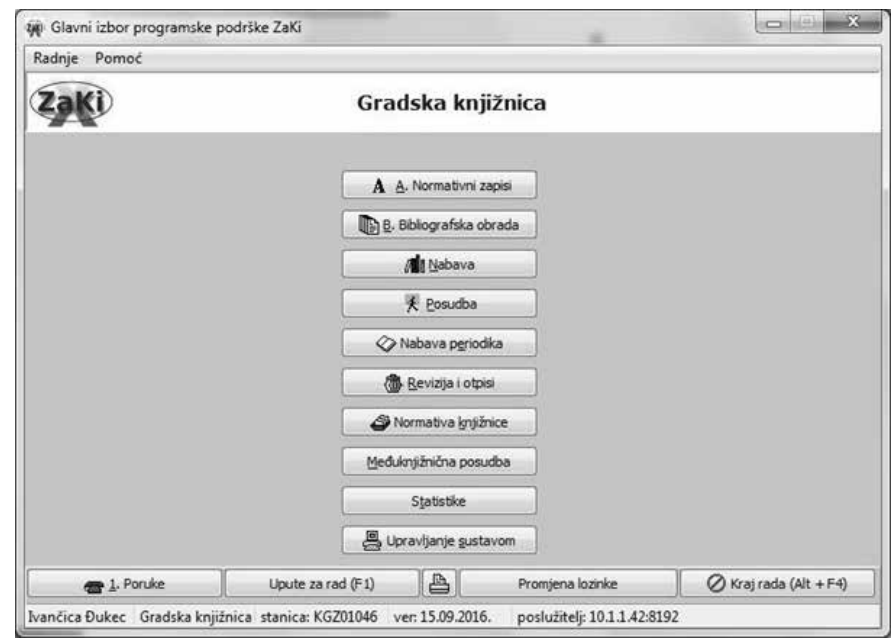

Slika 1 Moduli integriranog knjižničnog sustava ZaKi

Kako bi mogli pristupiti programu i intervenirati pri eventualnim problemima te osigurati kvalitetnu pomoć, u Matičnoj službi njezini djelatnici imaju najveće ovlasti za rad. Dostupnost i ovlašten pristup kompletnim bazama olakšavaju rad djelatnika Matične službe u smislu brze i jednostavne provjere podataka, racionaliziraju vrijeme u rješavanju problema i olakšavaju komunikaciju zahvaljujući mogućnosti pristupa pojedinoj lokaciji na daljinu.

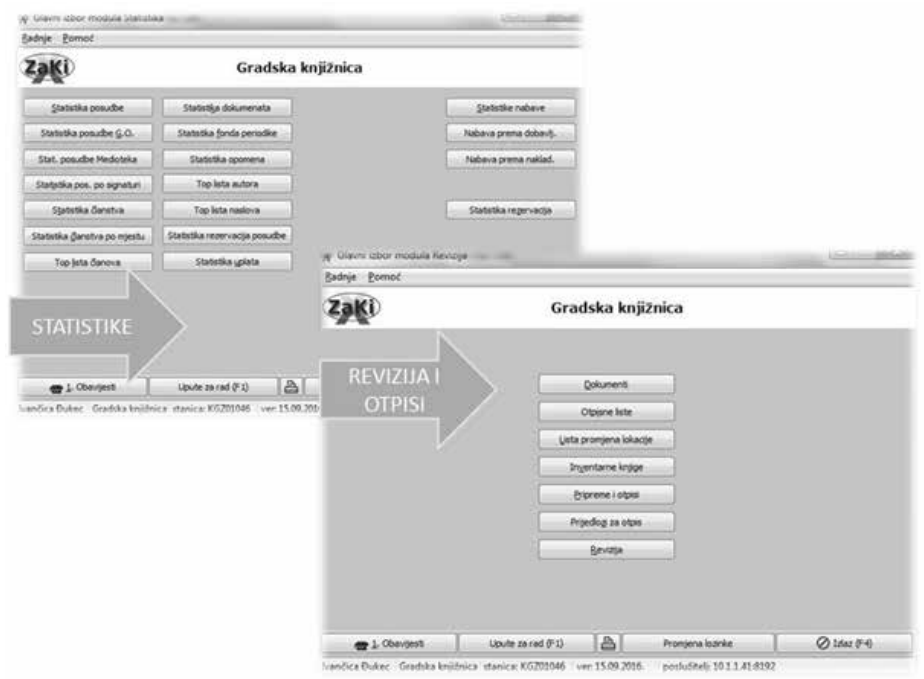

Slika 2 Moduli Statistika i Revizija i otpisi 


\subsection{Mogućnosti modula Revizija i otpisi}

Knjižnice se posljednjih godina suočavaju s kontrolom poslovanja koju provode gradski ili državni kontrolni uredi, s revizijama i drugim detaljnim provjerama poslovanja (slika 2). Jedan od najčešće kontroliranih segmenata unutar knjižnične djelatnosti svakako su i poslovi vezani uz reviziju i otpis knjižnične građe.

Po Pravilniku o reviziji i otpisu knjižnične građe ${ }^{7}$ „knjižnice su obvezne provoditi redovite revizije svojih fondova knjižnične građe periodično, ovisno o obimu knjižnične građe".

Provođenjem revizije u pojedinoj knjižnici detaljno se pregledava knjižnični fond te se utvrđuje njegovo stvarno stanje, njegova materijalna vrijednost i posljedice nastale uporabom knjižnične građe. ${ }^{8}$ Sukladno Pravilniku, građa se otpisuje po kriterijima uništenosti, dotrajalosti i zastarjelosti. Podaci dobiveni provođenjem revizije i redovnih otpisa služe kao pokazatelji o poslovanju knjižnice i od velike su važnosti i za kvalitetniju izgradnju fonda, zaštitu knjižnične građe te pružanje što bolje usluge korisnicima.

Iako je integrirani knjižnični sustav ZaKi i prije omogućavao provedbu revizije i otpisa u knjižnicama i sastavljanje otpisnih lista složenih prema autoru, inventarnom broju i signaturi, na sastanku Matične službe, Službe za informatiku i programerskog tima VIVA Info 2014. godine prepoznata je potreba za nadopunom modula koji bi taj važan segment poslovanja olakšao djelatnicima knjižnica. Kao stručni suradnici u samoj nadogradnji i poboljšanju modula, djelatnici Matične službe nastavili su nakon implementacije noviteta 2015. godine s pružanjem podrške za njega.

Novo sučelje za provedbu revizije omogućava lakšu kontrolu provođenja revizije cijelog fonda knjižnice jer u svakom trenutku nudi jednostavan uvid u evidentiranu građu, kao i uvid u onu koja tek treba proći evidenciju, a što se u prijašnjoj inačici programa moglo dobiti tek kroz unošenje više parametara koji se nisu mogli trajno pohraniti. Pomoću odabira lokacije i/ili određivanja signature, postupak revizije po potrebi se može i ograničiti na određeni dio fonda što knjižnicama s velikom količinom građe uvelike olakšava provođenje revizije parcijalno, u duljem razdoblju (slika 3).

\footnotetext{
7 Pravilnik o reviziji i otpisu knjižnične građe. // Narodne novine, broj 21/2002. Dostupno na http://narodne-novine.nn.hr/clanci/sluzbeni/2002_03_21_503.html [citirano: 2017-5-15].

8 Lalić, Maja. Zaštita građe. // Upute za poslovanje narodnih knjižnica / uredila Aleksandra Malnar. Zagreb : Knjižnice grada Zagreba, 1996. Str. 125.
} 


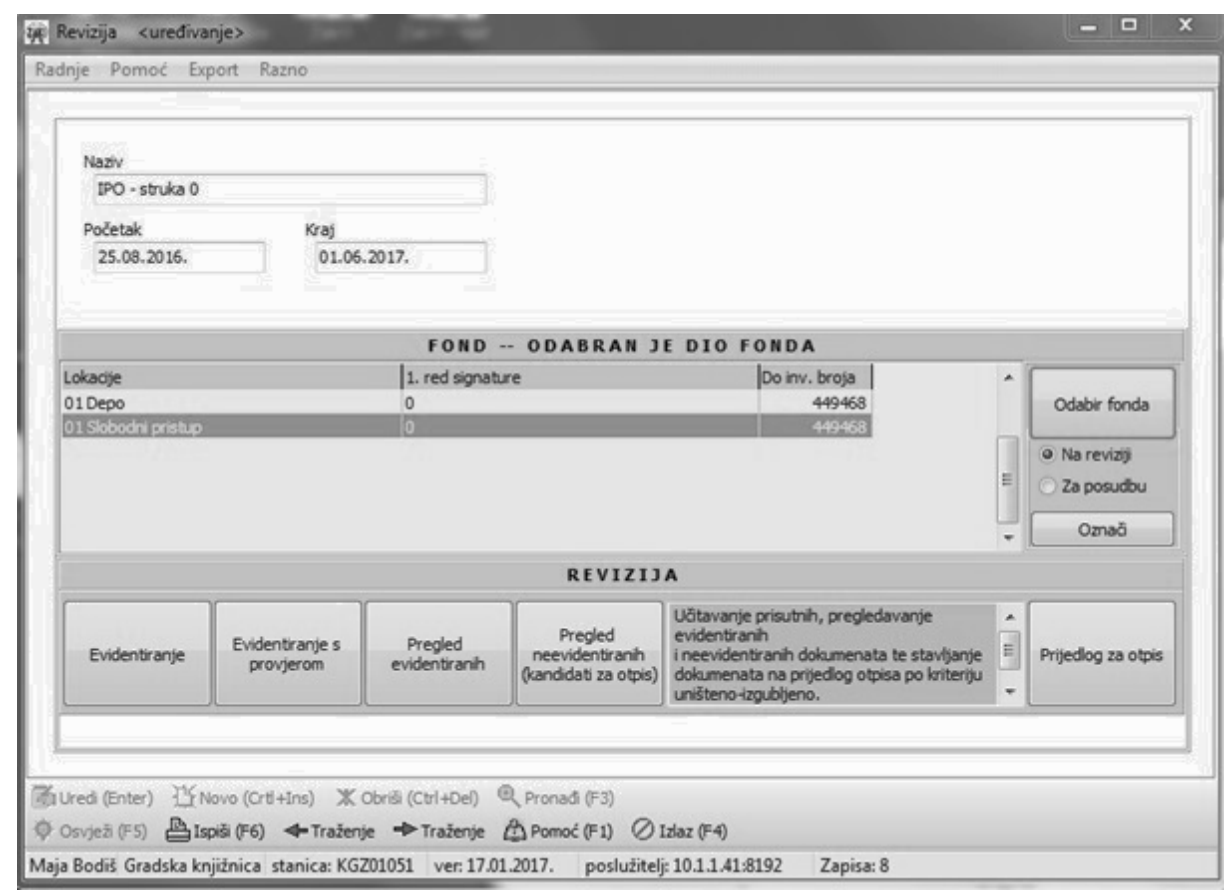

Slika 3. Prikaz postavljene revizije s ograničenjima po lokaciji, signaturi i inventarnom broju

Pravilnik o reviziji i otpisu knjižnične građe navodi kako su knjižnice „dužne i bez prethodno provedene revizije po potrebi tijekom godine odvajati za otpis dotrajalu i zastarjelu knjižničnu građu“ ${ }^{9}$ Knjižnični program ZaKi nudi temeljitiju provjeru fonda tijekom godine radi mogućeg otpisa knjiga koje su više puta posuđivane i time dotrajale ili u duljem razdoblju nisu bile posuđivane, pa su za određeni knjižnični fond zastarjele. Isto tako, moguće je provjeriti količinu građe koja dulje vrijeme nije vraćena od strane korisnika i kao uništena za knjižnicu može biti otpisana (slika 4).

9 Više o tome u Pravilnik. Nav. dj. 


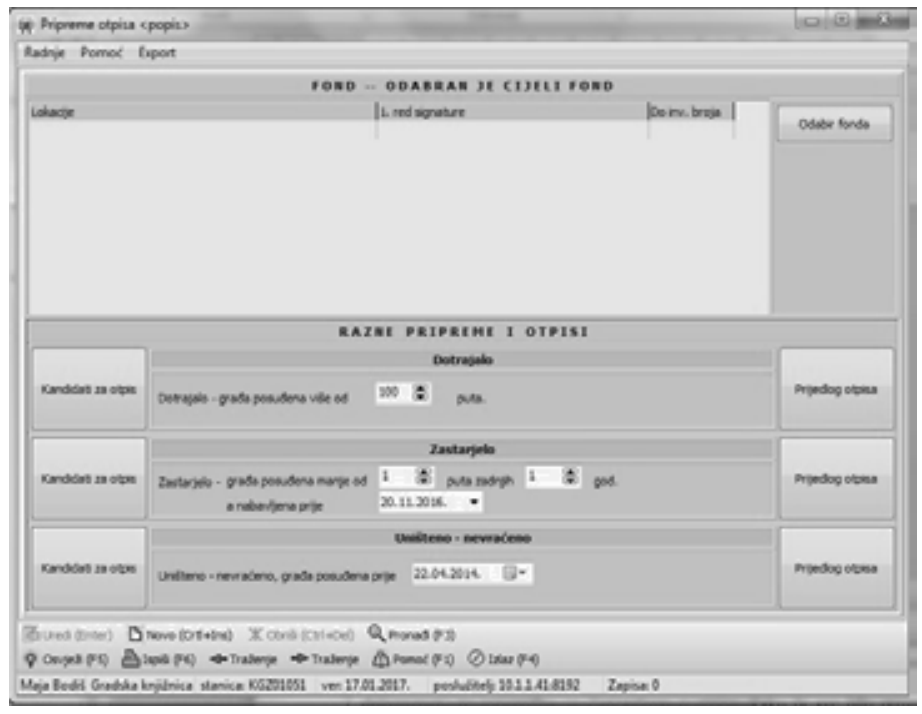

Slika 4. Pripreme otpisa

Za razliku od prijašnje zbirne liste predloženih dokumenata gdje djelatnici nisu mogli napraviti dodatnu kontrolu prije kreiranja Zapisničkog otpisa, novost u modulu Revizija i otpisi jest i dobivanje lista dokumenata predloženih za otpis po željenim parametrima. S obzirom da je kreiranje Zapisničkog otpisa unutar programa ZaKi konačna i nepovratna radnja, tako dobivene liste omogućavaju bolju pripremu dokumenata za otpis, promjenu kriterija prijedloga za otpis za jedan ili više dokumenata, kao i poništavanje prijedloga za otpis (slika 5).

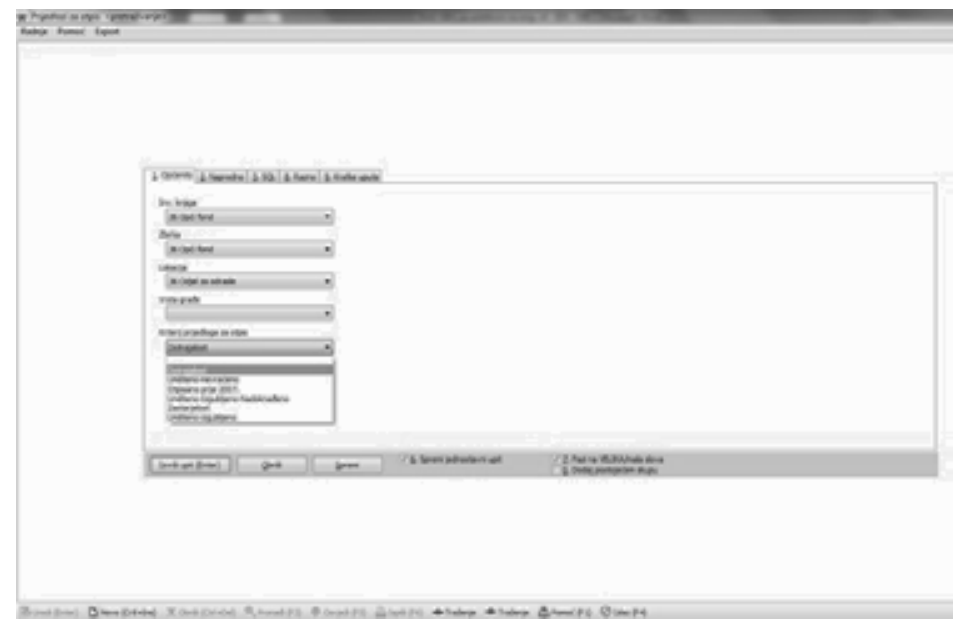

Slika 5. Zahtjev za ispis liste prijedloga za otpis 
Prilikom kreiranja Zapisničkog otpisa knjižnični program obavlja pozadinsku radnju u obliku kontrole posljednjih primjeraka na pojedinoj lokaciji i iste uvrštava u popis Desiderate kako bi djelatnici odjela nabave mogli što bolje izgrađivati fond.

Kako bi sve bilo provedeno sukladno Pravilniku o reviziji i otpisu knjižnične građe, djelatnicima Matične službe dodijeljena je posebna ovlast pristupa podacima o knjižničnoj građi bilo koje knjižnice sustava ZaKi, koja djelatnicima Matične službe omogućava davanje učinkovitije podrške prilikom provođenja revizije i otpisa. Bitno je istaknuti kako navedena ovlast djelatnicima Matične službe omogućava kvalitetniju kontrolu lista otpisanih dokumenata u knjižničnom programu jer su mu one vidljive na ekranu bez obzira na fizičku lokaciju knjižnice te usporedbu podataka iz programa sa Zapisnikom o otpisu koji pojedina knjižnica daje na uvid (slika 6). Na taj se način propusti kod kreiranja Zapisničkih otpisa pravodobno uočavaju i ispravljaju, a točnost informacija o fondu je zagarantirana.

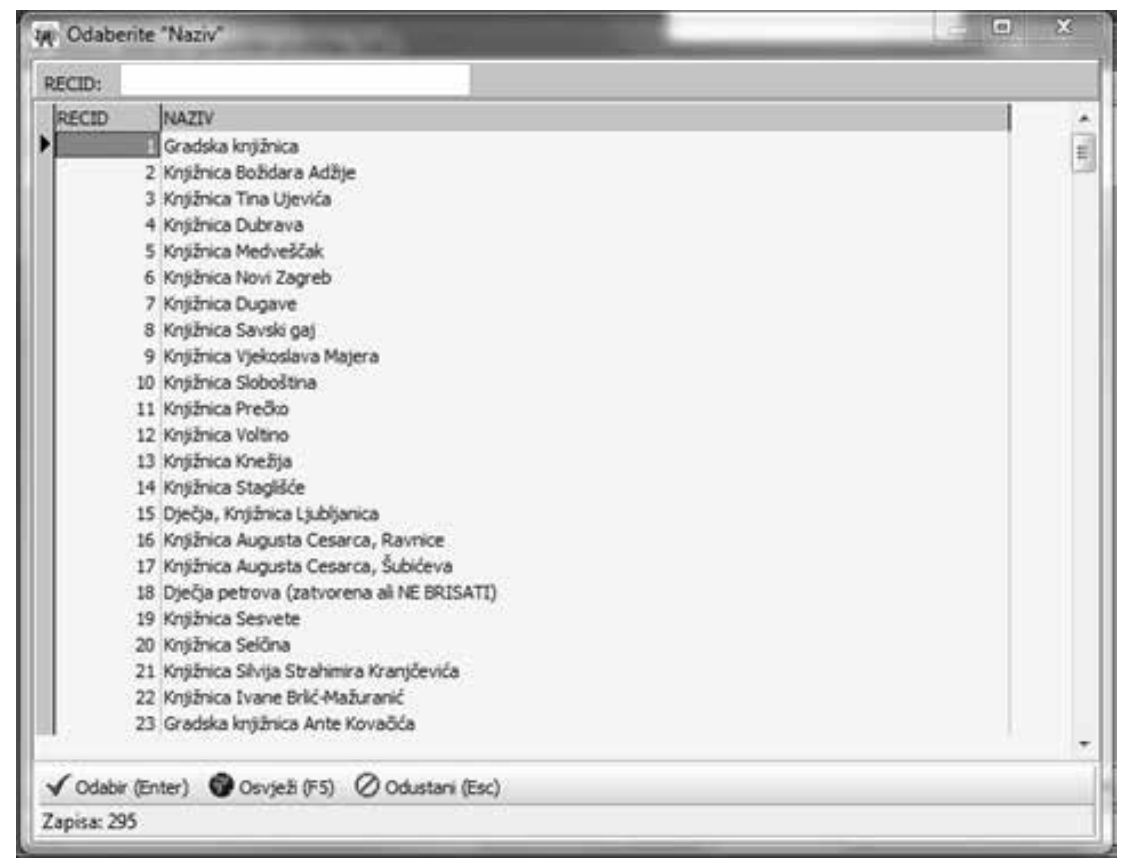

Slika 6. Promjena pristupa drugoj lokaciji

S obzirom na velik broj knjižnica u području svoje matičnosti, uvid u bazu pojedine knjižnice bez odlaska na njezinu lokaciju Matičnoj službi uvelike pomaže u racionalizaciji trošenja vremena. Na taj način omogućeno je odgovaranje na upite ili rješavanje poteškoća personalizirano i u najkraćem mogućem roku. Takva 
podrška na daljinu pokazala se vrlo korisnom i pozdravljena je od strane djelatnika knjižničnog sustava ZaKi jer im donosi brza rješenja te sigurnost u radu u modulu Revizija i otpisi.

Knjižnice novonabavljenu građu upisuju u elektroničku bazu te na taj način stvaraju elektroničku inventarnu knjigu. Različiti su razlozi zbog kojih nam može zatrebati ispis svih podataka iz inventarne knjige, ponekad se to radi u sklopu godišnjih izvještaja, ponekad i radi štićenja podataka, ali najvažniji je razlog svakako onaj koji nam propisuje Pravilnik o proračunskom računovodstvu i Računskom planu.

Prema odredbi članka 15. starog Pravilnika o proračunskom računovodstvu i Računskom planu ${ }^{10}$, popis imovine i obveza mora se sastaviti na kraju svake poslovne godine sa stanjem na datum bilance. Iznimno, proračun i proračunski korisnici koji obavljaju muzejsku, knjižničarsku ili bibliotečnu djelatnost popisivanje knjiga i bibliotečne građe mogu obaviti u roku koji nije dulji od tri godine.

U listopadu 2014. stupio je na snagu novi Pravilnik o proračunskom računovodstvu i Računskom planu ${ }^{11}$, kojim je propisano da proračun i proračunski korisnici koji obavljaju knjižničnu djelatnost popisivanje knjižnične građe mogu obaviti u roku koji nije dulji od roka za provođenje obvezne redovne revizije knjižnične građe utvrđenog posebnim podzakonskim aktom.

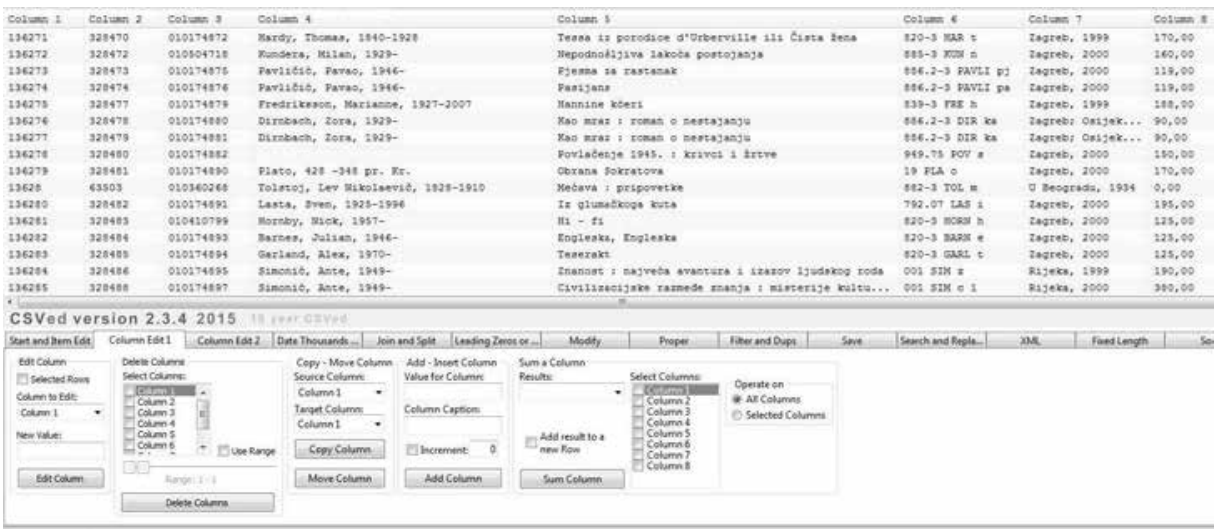

Slika 7. Ispis e-Inventarne knjige

10 Pravilnik o proračunskom računovodstvu i Računskom planu. // Narodne novine, broj 114/10 i 31/11. Dostupno na http://narodne-novine.nn.hr/clanci/sluzbeni/2010_10_114_3008.html [citirano: 2017-5-15].

11 Pravilnik o proračunskom računovodstvu i Računskom planu. // Narodne novine, broj 124/14, 115/15 i 87/16. Dostupno na http://narodne-novine.nn.hr/clanci/sluzbeni/2014_10_124_2374.html [citirano: 2017-5-15]. 
Bez obzira na to radi li se o manjoj knjižnici koja ima do 10000 jedinica knjižnične građe i obvezna je reviziju provesti svake četiri godine ili knjižnici s fondom do 500000 jedinica koja reviziju radi svakih 12 godina, popis imovine moraju napraviti i spremiti ga na odgovarajući način.

Za ustanovu kao KGZ koja ima preko 1300000 jedinica knjižnične građe u više od 140 inventarnih knjiga ispis na papiru bio bi vrlo složen i skup pothvat.

Da bi olakšao taj posao, KGZ koristi mogućnost eksporta podataka iz elektroničke baze knjižnične građe $\mathrm{u}$ csv-formatu ${ }^{12}$. Taj popis postoji samo u elektroničkom obliku, tj. ne ispisuje se. Ispis, odnosno eksport svih inventarnih knjiga KGZ-a radi se na kraju svake godine i uključuje samo postojeću, a ne i otpisanu građu, bez obzira je li u posudbi ili u knjižnici. Uzimaju se samo osnovni podaci o svakoj jedinici građe, kao što su inventarni broj, ident, autor, naslov, izdavač, godina, signatura i cijena (slika 7).

Zbog male veličine datoteka moguće ih je kopirati i na CD. Eksport svih inventarnih knjiga KGZ-a za 2016. nije veći od 300MB. Na CD se kopira i program CSVed, besplatni program za čitanje i rad s csv-datotekama. Program ne zahtijeva instalaciju i pokreće se dvostrukim „klikom“ na izvršnu datoteku "CSVed.exe”. Početkom svake godine po jedan primjerak CD-a i prateće dokumentacije arhivira se na dogovorenom mjestu.

\subsection{Mogućnosti modula Statistike}

O svojem djelovanju Matična služba izvještava osnivača Knjižnica grada Zagreba - Grad Zagreb - polugodišnjim i godišnjim izvještajima ${ }^{13}$, a Nacionalnu i sveučilišnu knjižnicu i Ministarstvo kulture redovitim godišnjim izvještajima. Osim „domaćih“ adresa na koje se statistički podaci o poslovanju redovito dostavljaju, Knjižnice grada Zagreba zahvaljujući članstvu u međunarodnim udruženjima, od 1968. godine u INTAMEL-u (Round Table of the International Association of Metropolitan Libraries), od 2003. godine u IFLA-i, a od 2010. godine u EBLIDA-i, imaju obvezu prikupljati, analizirati i distribuirati i statističke podatke zanimljive navedenim udruženjima. Stručnjaci iz Gradske knjižnice kroz navedeno su najstarije međunarodno članstvo, ono u INTAMEL-u, imali uvid u najnovije tendencije u razvoju mreža knjižnica u svjetskim metropolama ${ }^{14}$ iz čega su dijelom i proizašle promišljene strukture podataka koji se prate. Tako

\footnotetext{
12 „Comma separated values“, odnosno zarezom odvojene vrijednosti, format je u kojem su podaci odvojeni delimiterom, najčešće točka-zarezom (;). Moguće ga je čitati s bilo kojim preglednikom, zbog čega je to jedan od najčešće korištenih formata za razmjenu podataka.

13 Godišnji izvještaji Knjižnica grada Zagreba izdaju se od 2013. godine i kao tiskana publikacija kojoj je dodijeljen ISSN. Izvještaji su dostupni javnosti i na www.kgz.hr .

14 Belan-Simić, Alemka; Ivančica Đukec Kero. Strateško planiranje i javnozagovaračke aktivnosti Knjižnica grada Zagreba. // Vjesnik bibliotekara Hrvatske 58, 1-2(2015), str. 29-44.
} 
primjerice program omogućuje praćenje nekoliko grupa podataka u promatranom vremenskom razdoblju ili pak na godišnjoj ili polugodišnjoj razini, kao i raznovrsne kombinacije podataka. Primjerice omogućeno je praćenje podataka o nabavi knjiga, i to po strukturi (znanosti, beletristika, dječja knjiga, priručna literatura), kao i po načinu nabave (kupnja, dar, obavezni primjerak, zamjena ili pak otkup Ministarstva kulture ili Gradskog ureda za obrazovanje, kulturu i sport). Za periodičke publikacije dostupni su podaci o nabavi broja naslova i broja primjeraka. Program prati potrebe odjela nabave i posudbe, odnosno cirkulacije građe, pa se tako prema stručnim pravilima u njega unose i razne vrste neknjižne građe (AVE, nota, igračaka i ostalog što ulazi u fond knjižnične građe) koja se nabavlja, a koju je potom moguće pratiti i za potrebe brojnih vrsta izvještaja. O mogućnostima revizije i otpisa već je izneseno, ali zahvaljujući kombinacijama svih navedenih pokazatelja, lako je i jednostavno uvijek provjeriti ispravnost podataka što se tiče fonda knjižnične građe, s obzirom na brojčane odnose stanja fonda protekle godine, otpisa te novonabavljene građe u tekućoj godini. Važnost tih mogućnosti posebno dolazi do izražaja u slučajevima kontrole državne ili druge revizije.

Podaci o članovima koji su raspoloživi u ZaKiju isto se tako sustavno prikupljaju i strukturirani su prema dogovorenim pravilima s obzirom na kategorije koje se žele pratiti, uspoređivati i dovoditi u raznovrsne kombinacije s drugim pokazateljima (primjerice posudbom). Tako se mogu pratiti članovi i njihove aktivnosti i navike, a da se uzimaju u obzir i karakteristike poput spola, dobi, zanimanja ili pak školske spreme. Isto tako, na razini mreže knjižnica, kao što je slučaj s Knjižnicama grada Zagreba, moguće je razlikovati i dobiti točne podatke o tome koliko je članova (građana, odnosno koliki je broj osoba s članskom iskaznicom), a koliko aktivnih korisnika koji su registrirani na više lokacija istovremeno. Dakle korisnik svojom članskom iskaznicom mora potvrditi članstvo (registrirati se) u bilo kojoj drugoj knjižnici u mreži ukoliko ju želi koristiti, a knjižnice tada u svojim statističkim izvještajima broje te korisnike u svoje članstvo te planiraju aktivnosti za djecu i odrasle, nabavu građe i sve ostale usluge prema tom broju članova. Isto tako, pomoću tih pokazatelja planiraju i broj potrebnih djelatnika za realizaciju planova. Zbrojem registriranih članova mogao se dobiti podatak o ukupnom članstvu u Knjižnicama grada Zagreba (dakle ne o pojedinačnim osobama, već se na taj način mogla iskazati i brojka dobivena na temelju mogućnosti da jedna osoba bude registrirani član više knjižnica). „Od 2010. godine programska podrška cirkulacije/posudbe omogućila je da se u ukupnom registriranom godišnjem članstvu iskažu pojedine osobe sa svojom članskom iskaznicom. Tako se iz godine u godinu može utvrditi koliko je osoba koristilo Knjižnice grada Zagreba, odnosno dobiti zanimljiv podatak koliki je to postotak od ukupnog broja stanovništva (prema službenom popisu Državnog zavoda za statistike). Za razliku od te brojke, 
moguće je ustanoviti i koliki je ukupan broj registriranih članova u Knjižnicama grada Zagreba i iz toga saznati koliko je svaki član koristio istovremeno knjižnica unutar mreže pa tako primjerice proširiti istraživanje i provjeriti pretpostavku da su korištenju više knjižnica istovremeno sklonije odrasle osobe, za razliku od djece koja koriste najbližu knjižnicu." ${ }^{15}$

Posudba bilo koje vrste nabavljene građe (knjige, periodičke publikacije, AVE i ostale vrste građe) isto tako može se promatrati iz različitih perspektiva i u omeđenim vremenskim razdobljima, po pojedinim lokacijama ili ukupno na razini ustanove te se dovoditi u vezu s ostalim podacima (primjerice članovima).

Prethodno navedeno primjer je strukture izvještaja o radu i neke od mogućnosti prikupljanja i kombiniranja podataka za godišnji i polugodišnji izvještaj Knjižnica grada Zagreba koje ispunjavaju sve knjižnice u mreži, a Matična služba uobličava, komentira te objavljuje podatke na kraju godine (slika 8). Dakle, u Izvještaju koji se objavljuje i u tiskanom izdanju sadržani su svi podaci, od statističkih pokazatelja svih vrsta (nabave knjižnične građe, stanja knjižnične građe, revizije, otpisa, broja lisnih kataloga, članstva, posudbe, događanja, programa, posjeta, suradnji), kao i o programima koji su financirani kroz natječaj javnih potreba u kulturi Grada Zagreba i Ministarstva kulture Republike Hrvatske. Takvi su izvještaji prije svega nastali radi osnivača, u početku kao ne toliko atraktivne tablice s kratkim komentarom, međutim od kada su podaci i komentari uobličeni kao publikacija, lakše je privući i zainteresirati i druge segmente javnosti. Iz navedenog je vidljivo kako je tako dobivene podatke iz promatrane godine jednostavno postavljati u druge odnose i uspoređivati sa Standardima, prošlogodišnjim statistikama, planom i programom za tu godinu, ali i uspoređivati na međunarodnoj razini zahvaljujući razmjenama upitnika kroz međunarodnu suradnju.

\footnotetext{
15 Primjer iz Izvještaja Knjižnica grada Zagreba za 2014. godinu o članstvu: [ ... ] od 1. siječnja do 31. prosinca 2014. godine, Knjižnice grada Zagreba koristilo [je] 135.443 osoba ili 17 posto ukupnog stanovništva (prema popisu iz 2011. - 790.017 stanovnika). U skladu s preporukom Standarda da se članstvom u knjižnici obuhvati 15 posto stanovništva, taj je obuhvat nadmašen i jedan je od najvećih u Hrvatskoj. Ukupan broj registriranih članova u Knjižnicama grada Zagreba jest 213.583, što znači da je svaki član koristio najmanje 1,7 knjižnica. Veći broj knjižnica koriste usporedno odrasli članovi, dok djeca, u pravilu, koriste samo jednu knjižnicu. Dostupno na https://issuu.com/knjinicegradazagreba/docs/izvje_taj_2016./2 [citirano: 20175-15].
} 


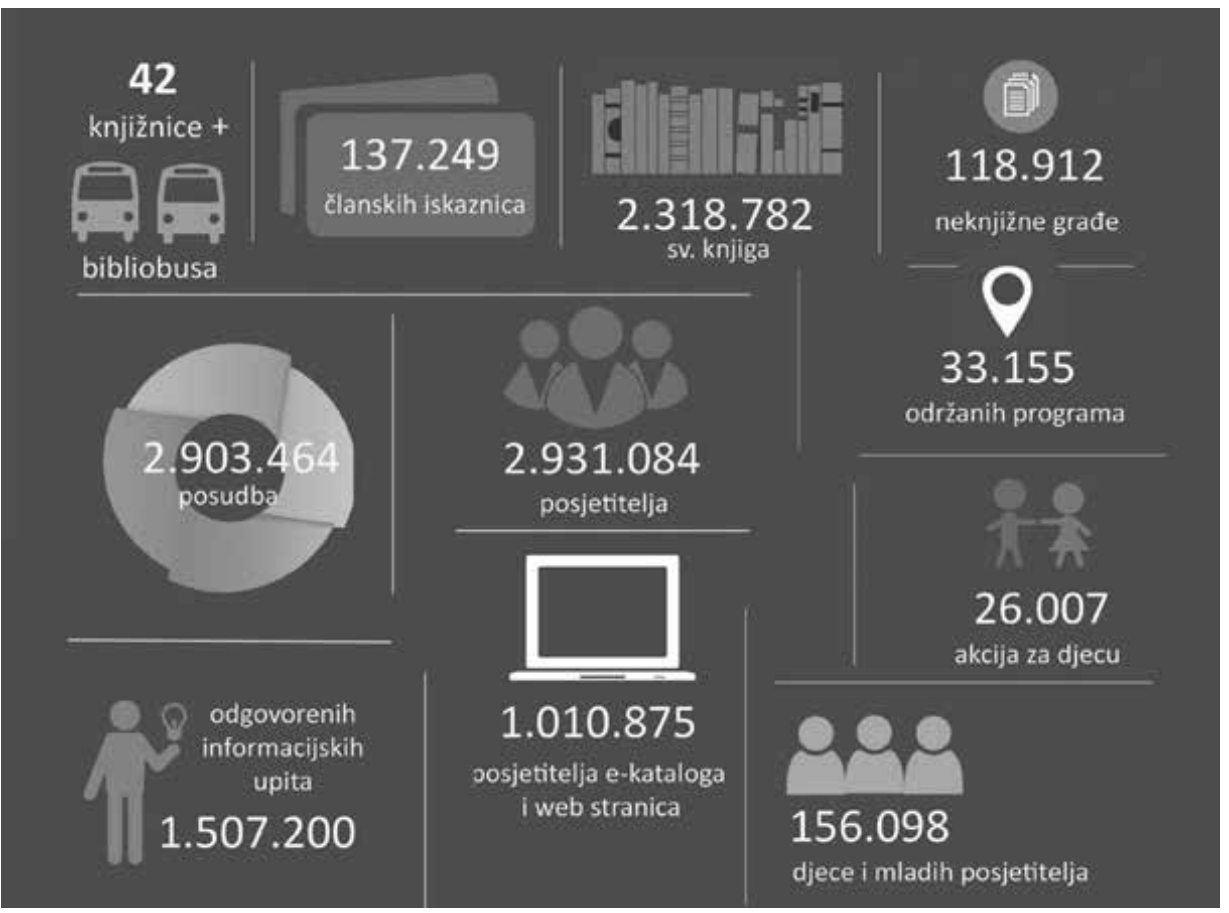

Slika 8. Primjer grafički uobličenih podataka za godišnji izvještaj Knjižnica grada Zagreba (www.kgz.hr)

Osim spomenutog, svakako ne treba izostaviti i zanimljivu i korisnu mogućnost koja je i dodana vrijednost modula Statistika, a to je jednostavno pribavljanje podatka o povijesti posudbe pojedinog člana (što je dostupno i svakom članu kroz katalog uz korištenje svoje iskaznice i pina), kao i pretraživanje povijesti posudbe pojedinog dokumenta u svrhu istraživanja, utvrđivanja eventualnih oštećenja na građi, kao i u druge raznovrsne svrhe. Isto tako, omogućena je pretraga statističkih podataka o posudbi po raznoraznim kriterijima, primjerice po signaturi. Kroz ZaKi su dostupni i drugi oblici korisnih statistika kao svojevrsna kontrola poslovanja, poput statistike nabave, rezervacija, uplate i opomena, ali i zanimljivi podaci, posebno atraktivni medijima, poput jednostavnog pronalaska top-ljestvica autora, naslova i članova. U smislu kontrole rada, ali i samokontrole djelatnika, unutar sustava olakšano je i praćenje promjena prema šifri djelatnika.

Bez obzira na to prikupljaju li se podaci za izvještaj, anketu Nacionalne i sveučilišne knjižnice, Državni zavod za statistiku, diplomske ili doktorske radove, za istraživanja ili pak medije, gotovo svi traženi podaci dostupni su kroz modul Statistike u ZaKiju, što značajno olakšava rad Matične službe $u$ analizi i usporedbi pokazatelja o građi i članovima, posudbi itd. Takvi točni, pouzdani i usporedivi 
podaci ključni su za korisnost i vrijednost knjižničnih statistika i kvalitetan temelj za razne usporedbe knjižnica unutar mreže, unutar županije i države, ali i s knjižnicama van Hrvatske.

Jedan od primjera kako statistički podaci zatraženi iz ZaKija mogu biti i zanimljivo štivo i poligon za raznovrsna istraživanja jest primjerice usporedba posudbe naslova autora ljubavnih romana Brende Joyce (slika 9) i autora kriminalističkih romana Joa Nesboa (slika 10) kroz zadnje dvije godine. Slike 9 i 10 grafički prikazuju odnos godina starosti korisnika i broja posudbi ljubavnih i kriminalističkih romana spomenutih autora među članovima KGZ-a. Na temelju pretraženih i dobivenih podataka mogu se donositi zaključci i raditi daljnje analize o tome čita li se više jedan ili drugi žanr, kakav je interes za ljubavne i kriminalističke romane s obzirom na spol korisnika, starosnu dob i sl. ${ }^{16}$ Takvi statistički podaci zanimljivo su „štivo“ za javnost, posebno medije koji vole kombinacije brojki i zanimljivih sadržaja.

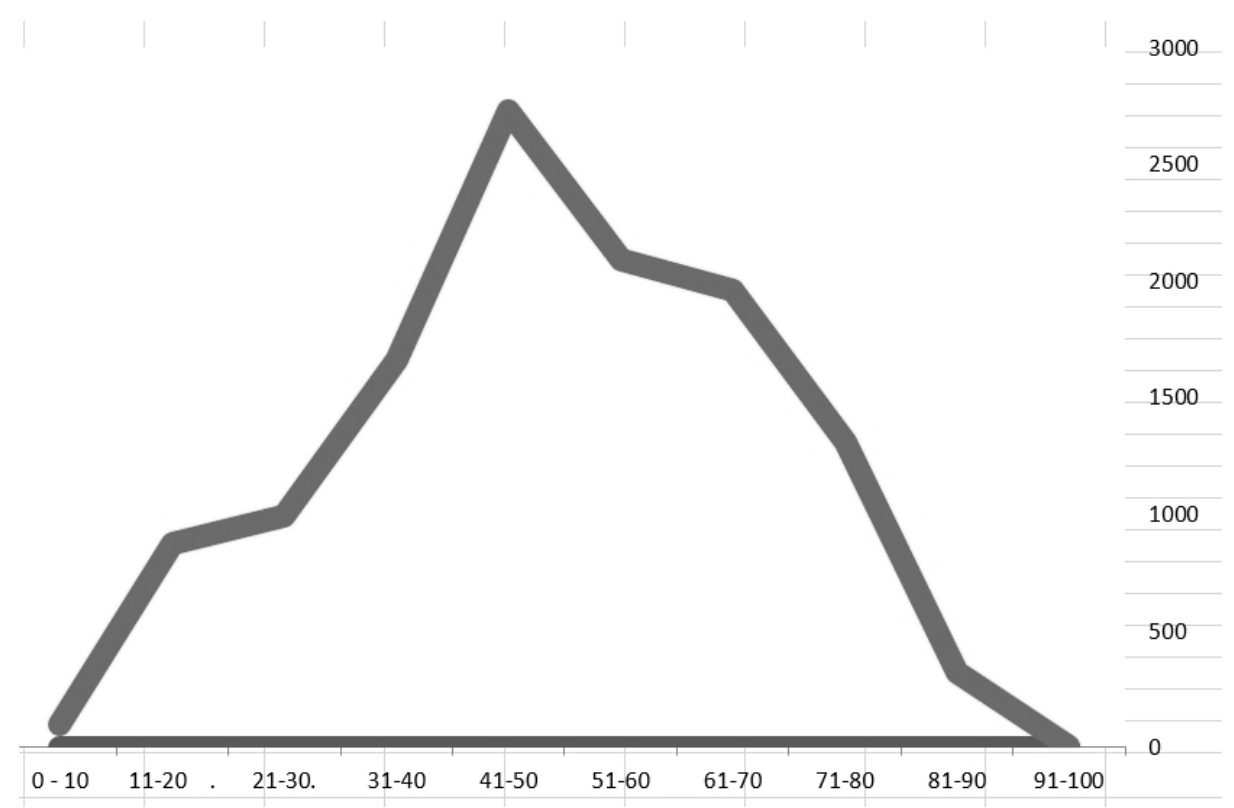

Slika 9. Čitanost ljubavnih romana autorice Brende Joyce među korisnicima KGZ-a u 2015. i 2016. godini

16 Dobiveni su očekivani podaci da ljubavne romane više čitaju ženski korisnici, dok muškarci i žene podjednako čitaju kriminalističke romane, što se može zaključiti s obzirom na udio muškaraca $(36 \%)$ u ukupnom broju korisnika Knjižnica grada Zagreba. 


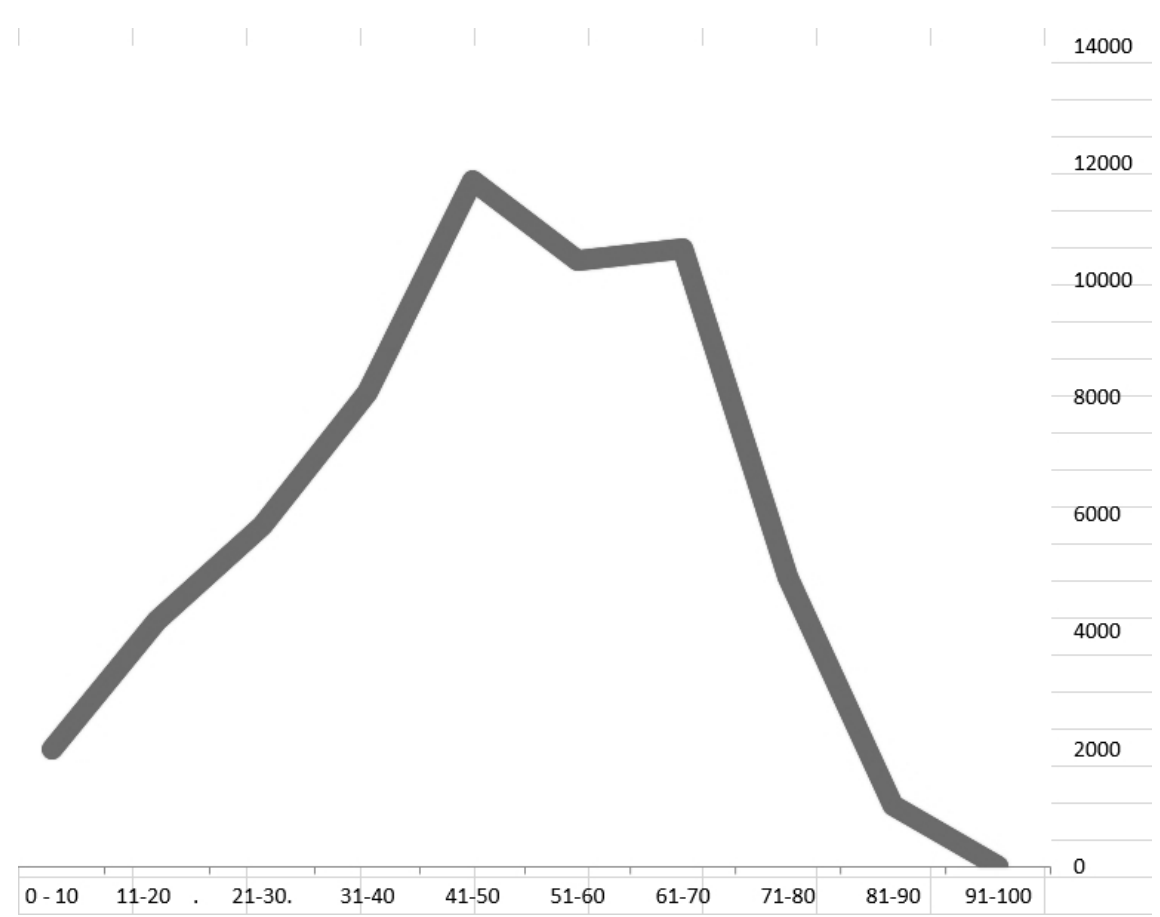

Slika 10. Čitanost kriminalističkih romana autora Joa Nesboa među korisnicima KGZ-a u 2015. i 2016. godini

\section{Zaključak}

Kvalitetan knjižnični sustav i kvantitativni i kvalitativni podaci o knjižničnom fondu, korisnicima i uslugama koje takav sustav omogućava, Matičnoj službi pomažu u učinkovitom upravljanju knjižnicama, stručnom radu, donošenju odluka te strateškom planiranju, praćenju razvoja, nadzoru, pa i osiguravanju pomoći knjižnicama u Gradu Zagrebu i Zagrebačkoj županiji. Pomoću tih podataka može se pratiti uspješnost poslovanja pojedine ustanove, praviti kvalitetne i pouzdane usporedbe s drugim ustanovama i knjižnicama, ali i planirati poslovanje za nadolazeća razdoblja. Analizom i kvalitetnim prezentiranjem dostupnih podataka održavaju se kvalitetni odnosi s osnivačima, ali i promoviraju knjižnične usluge i knjižnice svim vrstama javnosti ${ }^{17}$ na zanimljiv način. Isto tako, zahvaljujući izdaš-

17 Korisnička javnost u koju spadaju stvarni i potencijalni korisnici; poslovna javnost koja okuplja financijere, sponzore, donatore, prijatelje knjižnica; stručna javnost, odnosno konkurentske/ srodne institucije; intermedijalna javnost koja okuplja dobavljače, vlast, medije (kao posrednik između onog internog i onog vanjskog) i interna javnost, odnosno cjelokupna struktura, organi- 
nosti knjižničnih statistika koje omogućuje knjižnični program ZaKi, Knjižnice grada Zagreba mogu sudjelovati u brojnim međunarodnim istraživanjima, redovito pratiti i valorizirati svoj rad na međunarodnoj razini, kao i vršiti konstantnu usporedbu brojčanih pokazatelja s onima sličnih knjižnica u svijetu. Isto tako, jednostavnom dostupnošću statističkih podataka knjižničari mogu zadovoljiti potrebe brojnih domaćih istraživanja, poput onih koja osmisle studenti uz svoje mentore ili pak drugi stručni eksperti, stručna društva ili srodne institucije. Knjižnični sustav iza čijeg razvoja neprekidno stoji stručni tim knjižničara i informatičara svojevrstan je živi organizam koji se kontinuirano razvija i osluškuje trendove te potrebe na terenu. Tako trenutno pred sobom ima novi izazov, razradu platforme za posudbu e-knjige. Osim uobičajenih statističkih podatka, posljednjih godina od neprocjenjive je vrijednosti i dostupnost podataka u ZaKiju o posudbi domaćih autora. Stoga se kroz razvoj modula za posudbu e-knjiga posebna pozornost posvetila upravo tom segmentu, pa će se statistikama pribrajati i podaci o posudbi e-knjiga, što nije nevažno, posebno zbog posudbenog prava i naknade autorima.

\section{LITERATURA}

Belan-Simić, Alemka; Ivančica Đukec Kero. Strateško planiranje i javnozagovaračke aktivnosti Knjižnica grada Zagreba. // Vjesnik bibliotekara Hrvatske 58, 1-2(2015), str. $29-44$.

Đukec, Ivančica. Komuniciranje knjižnica $\mathrm{s}$ javnošću putem mrežnog mjesta : magistarski rad. Zadar : Filozofski fakultet Sveučilišta u Zadru, 2009.

Gomerčić, Nada. Matična služba Knjižnica grada Zagreba 1973.-1998. : 25 godina rada Matične službe. Zagreb : Knjižnice grada Zagreba, Matična služba, 1998. [interni dokument].

Izvještaj Knjižnica grada Zagreba. Dostupno na http://www.kgz.hr [citirano: 2017-515].

Pravilnik o reviziji i otpisu knjižnične građe. // Narodne novine br. 21/2002. Dostupno na http://narodne-novine.nn.hr/clanci/sluzbeni/2002_03_21_503.html [citirano: 2017-5-15].

Pravilnik o proračunskom računovodstvu i Računskom planu. // Narodne novine, broj 114/10 i 31/11. Dostupno na: http://narodne-novine.nn.hr/clanci/sluzbeni/2010_10_114_3008.html [citirano: 2017-5-15].

Pravilnik o proračunskom računovodstvu i Računskom planu. // Narodne novine, broj 124/14, 115/15 i 87/16). Dostupno na: http://narodne-novine.nn.hr/clanci/sluzbeni/2014_10_124_2374.html [citirano: 2017-5-15].

zacija, djelatnici narodne knjižnice. Prema: Đukec, Ivančica. Komuniciranje knjižnica s javnošću putem mrežnog mjesta: magistarski rad. Zadar : Filozofski fakultet Sveučilišta u Zadru, 2009. 
Knjižnice grada Zagreba: Strateški plan 2014.-2020. Zagreb : Knjižnice grada Zagreba, 2013. [interni dokument].

Lalić, Maja. Zaštita građe. // Upute za poslovanje narodnih knjižnica / uredila Aleksandra Malnar. Zagreb : Knjižnice grada Zagreba, 1996. Str. 121-133.

Zakon o knjižnicama. // Narodne novine, broj 105/97, 05/98, 104/00, 69/09. Dostupno na: https:/www.zakon.hr/z/745/Zakon-o-knji\%C5\%BEnicama [citirano: 2017-5$15]$. 